\title{
PENERAPAN NOMOR FILE DALAM MANAJEMEN OPERASIONAL REKAM MEDIS BERDASARKAN WILAYAH DI PUSKESMAS MUKA
}

\author{
Adinda Amalia Nurussyifa ${ }^{1 *}$, Nisa Sri Penti ${ }^{2}$, Irda Sari ${ }^{3}$ \\ Politeknik Piksi Ganesha Bandung, Indonesia ${ }^{1,2,3}$ \\ aanurussyifa@piksi.ac.id ${ }^{1 *}$, nspenti@piksi.ac.id ${ }^{2}$,irda.sari@piksi.ac.id ${ }^{3}$
}

Received: 17-07-2021

Revised: 18-10-2021

Accepted: 19-10-2021

\begin{abstract}
Abstrak
LatarBelakang: Proses penomoran berkas rekam medis di Puskesmas Muka Cianjur masih menggunakan cara manual sehingga berkas rekam medis tidak berurutan dan berantakan. Masalah tersebut terjadi karena keterbatasan sumber daya manusia, Puskesmas Muka hanya memiliki satu staf Rekam Medis dan tenaga non Rekam medis untuk memudahkan dalam pencarian dan penyimpanan berkas rekam medis maka diterapkan sistem penomoran file berdasarkan wilayah tempat tinggal pasien yang dibagi menjadi 3 kelompok daerah terdekat Puskesmas meliputi Kelurahan Muka, Kelurahan Bojong Herang, dan kelurahan Babakan Karet adapun khusus untuk pasien Luar Wilayah dari 3 kelurahan tersebut dimasukkan kedalam file "Luar Wilayah".
\end{abstract}

Tujuan: Tujuan diadakannya penelitian ini adalah untuk mengetahui penerapan nomor file bedasarkan wilayah tempat tinggal pasien.

Metode: Metode penelitian yang digunakan yaitu deskriptif dengan pendekatan kualitatif dan fenomological kepada 3 orang staf dan karyawan Puskesmas Muka Cianjur.

Hasil: Dari hasil penelitian yang kami temukan bahwa masih terdapat masalah, baik dari faktor internal maupun eksternal rekam medis di Puskesmas Muka. Masih terdapat berkas yang hilang di luar ruangan rekam medis, Penerapan Nomor File ini adalah untuk memudahkan setiap petugas untuk pengambilan ataupun pengembalian berkas.

Kesimpulan: Penerapan Nomor file di Puskesmas Muka Cianjur ini diterapkan untuk memudahkan petugas untuk mencari berkas pasien yang berisi identitas pasien sesuai KTP/Surat tanda pengenal lainnya.

Kata kunci: rekam medis; nomor file; puskesmas.

\begin{abstract}
Background: The process of numbering medical record files at Puskesmas Muka Cianjur still uses the manual method so that the medical record files are not sequential and messy. This problem occurs due to limited human resources, PuskesmasMuka only has one medical record staff and non-medical record staff to facilitate the search and storage of medical record files, a file numbering system
\end{abstract}




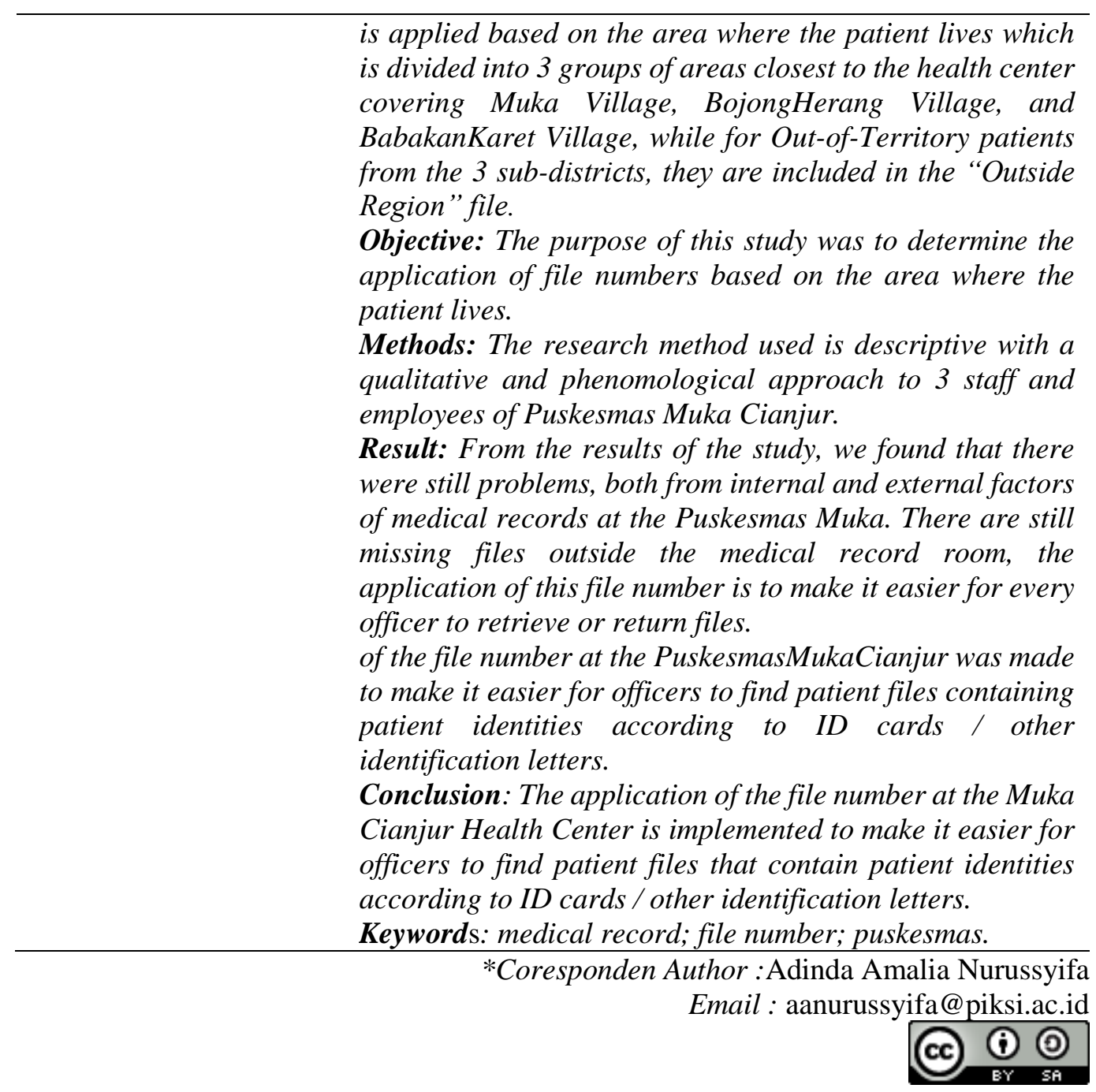

\section{PENDAHULUAN}

Puskesmas adalah salah satu fasilitas kesehatan tingkat pertama yang menyelenggarakan pengobatan untuk warga terdekat yang ada di sekitar wilayah kerja puskesmas guna mencapai kesehatan yang optimal untuk masyarakat luas. Sama dengan rumah sakit, puskesmas juga harus memiliki rekam medis yang penyelenggaraannya tentu saja berkiblat pada aturan khusus yang ada di Kementrian Kesehatan Republik Indonesia. Belum spesifik adanya penyelenggaraan rekam medis di puskesmas sehingga terjadi perbedaan penyelenggaraan di setiap puskesmas di seluruh Indonesia (Anita \& Febriawati, 2019).

Penyelenggaraan rekam medis telah diatur dalam Undang-Undang No. 29 Tahun 2004 tentang praktik kedokteran dan Permenkes No. 269 Tahun 2008 tentang rekam medis (Indonesia, 2004). Menurut Permenkes Nomor 269/MENKES/PER/III/2008, rekam medis adalah berkas yang berisikan catatan dan dokumen tentang identitas pasien, pemeriksaan, pengobatan, tindakan dan pelayanan lain yang telah diberikan kepada pasien (Permenkes, 2008). Rekam medis merupakan suatu catatan baik yang tertulis maupun yang terekam, berisikan identitas pasien, anamnesa, pengobatan diagnosis, tindakan serta pelayanan lainnya yang diberikan oleh petugas kepada pasien baik pelayanan rawat jalan, rawat inap maupun gawat darurat (프, 2006). 
Rekam medis merupakan suatu catatan baik yang tertulis maupun yang terekam, berisikan identitas pasien, anamnesa, pengobatan diagnosis, tindakan serta pelayanan lainnya yang diberikan kepada pasien, Rekam kesehatan yang mencatat siapa, apa, kapan, dimana dan bagaimana perawatan pada pasien. Rekam medis merupakan suatu catatan baik yang tertulis maupun yang terekam, berisikan identitas pasien, anamnesa, pengobatan diagnosis, tindakan serta pelayanan lainnya yang diberikan kepada pasien, Rekam kesehatan yang mencatat siapa, apa, kapan, dimana dan bagaimana perawatan pada pasien (Hidayat, 2012).

Prosedur penerimaan pasien di salah satu Puskesmas di Cianjur yaitu Puskesmas Muka adalah pasien wajib membawa nomor antrian sebelum dipanggil oleh petugas pendaftaran, lalu sesuaikan dengan jadwal poli yang tersedia yang dibagi menjadi 6 poli yaitu umum (Khusus lansia 50 tahun ke atas), KIA (Kesehatan Ibu dan Anak), MTBS (Manajemen Terpadu Balita Sakit), DOTS (Paru-Paru), dan Gigi (Estera, 2018).

Pasien akan dipanggil oleh petugas lalu dimintai nomor antrian dan kartu identitas, ada pasien umum dan pasien BPJS, bila pasien umum akan di input ke dalam aplikasi SIKDA GENERIK dan pasien BPJS akan di input dalam P-CARE BPJS, bila pasien lama petugas akan meminta kartu berobat pasien dan itu pertanda bahwa pasien sudah pernah berobat sebelumnya, bila pasien sudah pernah berobat biasanya pengelolaan berkas rekam medis akan lebih cepat karena data pasien sudah tertera pada aplikasi, berbeda dengan pasien baru biasanya pasien baru akan lebih lama karena petugas harus menulis identitasnya (Wahyuni, 2021).

Dalam Kartu Berobat itu tercantum No File, Nama Kepala Keluarga/KK, No Rekam Medis pasien, alamat dan baris untuk beberapa keluarga yang datang untuk berobat lagi. Biasanya pasien yang sudah pernah berobat lalu kedatangan berikutnya oleh anggota keluarga lainnya itu akan dijadikan satu Nomor File tetapi berbeda nomor rekam medis, map untuk keduanya pun dibedakan karena khawatir jika mereka bersama-sama berobat lalu berbeda poli itu akan cukup memakan waktu yang sangat banyak, oleh sebab itu, penggunaan family folder pun dihapuskan oleh Puskesmas karena banyak menyita waktu terlebih banyak kasus pasien berobat bersama-sama satu keluarga tetapi beda poli.

Begitupun dalam berkas pasien, Nomor File dicantumkan karena untuk pasien yang datang berobat tahun 2019 belum memakai map sesuai ketentuan masih kertas saja sehingga didalam berkas nya pun diberi kolom Nomor File di pojok kanan atas, lalu identitas pribadi dan catatan dari dokter. Sebelumnya Rekam Medis ini tidak diwajibkan di setiap Faskes tentu saja pemberkasan ini diatur oleh tenaga non Rekam medis sehingga terjadinya beberapa masalah, salah satunya yaitu penumpukan dan banyaknya berkas pasien yang hilang atau rusak, ketika pasien datang dan hendak berobat petugas harus mencari berkas yang tidak tersusun sehingga menyebabkan lemahnya respon time Rekam medis dan terkadang dokter mendiagnosa pasien sesuai dengan riwayat pasien sebelumnya.

Dalam uraian yang dikemukakan di atas, untuk memudahkan petugas rekam medis dalam pengelolaan berkas rekam medis maka dilakukan penerapan nomor file berdasarkan wilayah tempat tinggal pasien. Agar terciptanya rekam medis yang bermutu, lengkap dan akurat, maka perlu adanya kerjasama yang baik antara Dokter, Perawat, Bidan, Perekam Medis dan tenaga kesehatan lainnya.

Bidang teknologi yang semakin maju membuat semua pekerjaan di dunia ini tidak lepas dari sistem, begitupun bidang kesehatan khususnya Puskesmas baik hardware maupun software-nya. Dengan adanya teknologi ini akan memudahkan kita untuk mengerjakan sesuatu apalagi untuk sistem pendaftaran, Puskesmas Muka sudah memakai aplikasi pendaftaran online yaitu Sikda Generik, semua identitas mengenai pasien akan di input, tetapi tidak ada kolom untuk menambahkan Nomor File lalu petugas mensiasati untuk menambahkannya di kolom alamat dengan format (file ; 01/21) yang berarti pasien pertama yang berobat di tahun 2021. Tujuan dari penelitian ini adalah untuk mengetahui pengaruh penerapan nomor file dalam manajemen operasional rekam medis berdasarkan wilayah di Puskesmas Muka. Penerapan Nomor File ini hanya diterapkan di Puskesmas 
Muka saja dan tidak ada di standar Rekam Medis dan undang-undangnya tetapi, cara ini bisa memudahkan petugas mencari dan mengembalikan berkas rekam medis.

\section{METODE PENELITIAN}

Metode pengumpulan data yang digunakan dalam penelitian ini adalah metode penelitian kualitatif dengan pendekatan fenomenologi (Subadi, 2006). Penelitian kualitatif dilakukan pada objek alamiah yang berkembang apa adanya, tidak dimanipulasi oleh peneliti dan kehadiran peneliti tidak begitu mempengaruhi dinamika pada objek tersebut. Tempat dan waktu penelitian dilakukan di Puskesmas Muka Cianjur pada tanggal 12 April12 Juni 2021. Penelitian kualitatif instrumennya adalah manusia atau peneliti itu sendiri. Untuk menjadi peneliti, maka harus memiliki bekal teori dan wawasan luas. Sehingga peneliti mampu bertanya, menganalisis, memotret dan mengkonstruksi situasi sosial yang diteliti menjadi lebih jelas dan bermakna. Adapun teknik pengumpulan data yang penulis lakukan dalam penelitian ini adalah dengan cara observasi dan wawancara.

\section{HASIL DAN PEMBAHASAN}

\section{A. Hasil Penelitian}

Tabel1. Karakteristik Informan Penelitian

\begin{tabular}{cccll}
\hline KodeInforman & Umur & Pendidikan & Jabatan & \multicolumn{1}{c}{$\begin{array}{c}\text { Status } \\
\text { Informan }\end{array}$} \\
\hline EM & 24 Tahun & D3Rekam Medis & $\begin{array}{l}\text { Penanggungjawab } \\
\text { Rekam Medis }\end{array}$ & $\begin{array}{l}\text { Informan } \\
\text { Kunci }\end{array}$ \\
\hline RS & 27 Tahun & SMK & $\begin{array}{l}\text { Penginputan } \\
\text { Rekam Medis }\end{array}$ & Informan Biasa \\
\hline AS & 46 Tahun & SMK & Pengolahan Data & Informan Biasa \\
\hline
\end{tabular}

Berdasarkan tabel 1 di atas diketahui bahwa jumlah informan yang diwawancarai dalam penelitian ini sebanyak 3 orang petugas rekam medis dengan rincian 1 orang Kepala Rekam Medis (Informan Kunci) dan 2 orang Petugas Rekam Medis (Informan Biasa). Adapun hasil wawancara penelitian ini adalah sebagai berikut :

\section{Informasi Mengenai Sistem Penomoran File Rekam Medis}

Berdasarkan hasil wawancara dari informan EM diperoleh informasi bahwa sistem penomoran file rekam medis di puskesmas muka menggunakan nomor urut kedatangan pasien dan tahun berobatnya. Apabila ada pasien yang berobat di tahun 2018 maka nomor dan mapnya harus dibayarkan ke 2021, seperti yang diungkapkan oleh ES sebagai berikut:

"sistem penomorannya pakai nomor urut kedatangan pasien dan tahun berobatnya, kendalanya sering terjadi nomor file yang berlapis karena human error dari petugas pendaftaran yang tidak tahu alamat tersebut adanya di kelurahan mana. Jadi, biasanya berkas pasien yang seharusnya masuk ke kelurahan bojong herang malah masuk ke kelurahan muka karena nama alamatnya hampir mirip"(EM, 24 tahun, 20 April 2021)."

"Jadi penomoran file ini dibagi menjadi 3 kelompok daerah terdekat Puskesmas neng, yaitu meliputi Kelurahan Muka, Kelurahan Bojong Herang, dan kelurahan Babakan Karet. Jika ada pasien Luar Wilayah dari 3 kelurahan tersebut dimasukkan kedalam file luar wilayah" (EM, 24 Tahun, 26 April 2021)." 
Informan lain mengatakan awalnya sistem penomoran file di Puskesmas Muka menggunakan cara manual dengan menulis di kertas dari nomor urut 1-100 untuk periode tertentu, setiap pasien datang nomor yang dipakai akan dicoret di kertas tersebut lalu setelah teknologi semakin berkembang di buatkanlah aplikasi pemakaian nomor file sesuai dengan kelurahan pasien tersebut seperti yang dikatakan oleh RS dan AS sebagai berikut :

"kalau dulu, teteh masih menulis di kertas nah yang dipakai itu dicoret satu-satu mungkin untuk mengirit pemakaian kertas di buatkanlah aplikasi nya tapi kadang kalau ada yang tidak mengerti pada aplikasi itu nomor file jadi dipakai $2 x$ atau terlewat itu dampaknya jadi bingung ke petugas yang cari berkas, kadang harusnya pasien lama jadi baru karena ada miss communication antar petugas pendaftaran dan pengolahan data dan berdampak juga pada respon time" (RS, 27 tahun, 25 Mei 2021)."

"tapi penerapan nomor file ini sangat membantu neng, karena kan dari awalnya berkas ini tercecer dan dulu masih belum disimpan di rak penyimpanan masih ditumpuk di dalam satu wadah disatukan semua kelurahan, kenapa diterapkan nomor file ini karena ketika kami kebingungan menyusun dari mana sedangkan nomor rekam medis sudah mencapai ribuan, kami kesulitan menemukan file nomor 01 nya" (AS, 46 tahun, 31 mei 2021)."

Dapat disimpulkan bahwa penerapan nomor file pada berkas rekam medis pasien di Puskesmas Muka itu ada kelebihan dan kekurangannya, yang pasti penerapan sistem penomoran file rekam medis dilakukan untuk memudahkan pencarian berkas pasien yang sudah pernah berobat.

\section{Informasi Mengenai Sistem Penyimpanan Setelah Penerapan Nomor File}

Berdasarkan hasil wawancara dengan informan diperoleh juga mengenai sistem penyimpanan setelah dilakukan penerapan nomor file di Puskesmas Muka yaitu dengan cara dipisahkan sesuai kelurahan tempat tinggal pasien dan tahun berkunjungnya dimulai dari tahun 2018, tetapi apabila pasien tahun 2018 datang berobat kembali di tahun 2021 makan nomor file nya harus dibayarkan ke 2021.

"Penyimpanan berkas rekam medis juga sama berdasarkan wilayah tempat tinggal pasien yang disebutkan tadi neng yaitu meliputi Kelurahan Muka, Kelurahan Bojong Herang, dan kelurahan Babakan Karet. Kalau ada pasien Luar Wilayah dari 3 kelurahan tersebut dimasukkan kedalam file luar wilayah" (ES, 24 Tahun, 22 April 2021)."

"Kalau ada pasien yang berobat tahun 2018 terus pasien tersebut berobat kembali tahun 2021, maka nomor filenya akan dibarukan kembali menjadi tahun 2021 neng"'(RS, 27 tahun, 3 Mei 2021)."

Informan juga mengatakan bahwa sistem penyimpanan rekam medis di Puskesmas Muka dengan cara sentralisasi yaitu menyimpan 1 rekam medis di dalam satu map baik rawat jalan maupun gawat darurat yang terdapat catatan kunjungan, catatan poliklinik, maupun catatan-catatan lainnya. Hal ini diterapkan karena untuk mengurangi penggunaan map secara berlebihan dan dapat memudahkan dokter untuk melihat riwayat penyakit sebelumnya.

"sistem penyimpanan berkas rekam medis di puskesmas ini yaitu dengan cara menggabungkan berkas rawat jalan, gawat darurat, catatan poliklinik dan catatan-catatan lainnya supaya lebih menghemat penggunaan map" (AS, 46 tahun, 27 mei 2021)."

\section{B. Pembahasan}

\section{Informasi Mengenai Sistem Penomoran File Rekam Medis}

Penomoran rekam medis adalah sistem yang digunakan untuk upaya pemberian identitas supaya penyimpanan jadi lebih mudah dan pengolahan data juga jadi lebih mudah 
(Simanjuntak \& menkes.ris Sirait, 2018). Nomor rekam medis adalah nomor pengenal yang unik, sebagai pengenal rekam medis pada setiap pasien, diberikan sesegera mungkin setelah pasien masuk (admission number)/pelayanan pertama setelah pasien masuk dan pemberian nomor ini merupakan cara terbaik yang dapat menjamin penemuan kembali berkas rekam medis pasien untuk kesinambungan pelayanan berikutnya (Deharja, 2021). Menurut pedoman pengelolaan rekam medis tahun 2006 revisi III ada 3 sistem penomoran yaitu seri, middle dan parallel.

Tetapi, sistem pengelolaan rekam medis di puskesmas belum ada pembahasan yang cukup jelas sehingga setiap puskesmas mempunyai cara tersendiri termasuk yang diadakan di puskesmas muka ini, penerapan nomor file dalam manajemen operasional ini bisa memudahkan pengelolaan rekam medis (Maliang et al., 2019).

Berdasarkan hasil wawancara juga, sistem penomoran rekam medis tetaplah ada tentunya setiap pasien memiliki 1 rekam medis untuk setiap kali berobat. Dalam Kartu berobat, Registrasi berkas keluar-masuk, Map dan formulir pun ada kolom untuk nomor file pasien yang mana setiap keluarga mendapatkan 1 nomor file yang sama tetapi berbeda nomor rekam medis.

Sistem penyimpanan merupakan suatu kegiatan menyimpan rekam medis bertujuan untuk melindunginya dari kerusakan fisik dan isi dari dokumen tersebut (Wiguna \& Safitri, 2019). Sistem penyimpanan berdasarkan wilayah merupakan jenis penyimpanan rekam medis berdasarkan wilayah yang ada dilingkungan fasilitas pelayanan kesehatan berada (Rahayu et al., 2016). Tempat untuk penyimpanan rekam medis akan dikelompokkan berdasarkan nama wilayah yang ada sehingga rekam medis pasien akan disimpan berdasarkan wilayah tempat tinggalnya.

Berdasarkan hasil wawancara dan observasi diperoleh informasi bahwa penyimpanan berkas rekam medis di Puskesmas Muka Cianjur diterapkan sistem penomoran file berdasarkan wilayah tempat tinggal pasien yang dibagi menjadi 3 kelompok daerah terdekat Puskesmas meliputi Kelurahan Muka, Kelurahan Bojong Herang, dan kelurahan Babakan Karet adapun khusus untuk pasien Luar Wilayah dari 3 kelurahan tersebut dimasukkan kedalam file "Luar Wilayah". Menurut (Mandia, 2019), sistem penyimpanan berkas rekam medis secara sentralisasi yaitu suatu sistem penyimpanan dengan cara menyatukan berkas rekam medis pasien rawat jalan, rawat darurat, dan rawat inap kedalam satu folder tempat penyimpanan.

Berdasarkan hasil wawancara dengan informan, sistem penyimpanan berkas rekam medis yang digunakan di Puskesmas Muka Cianjur menggunakan Sistem Sentralisasi, yaitu suatu sistem penyimpanan dengan cara menyatukan satu map baik rawat jalan maupun gawat darurat yang terdapat catatan kunjungan, catatan poliklinik, maupun catatan-catatan lainnya dalam satu folder ( Rachma, 2018).

\section{KESIMPULAN}

Dari hasil wawancara dan penelitian selama 2 bulan dapat ditemukan bahwa penerapan nomor file dalam manajemen operasional di Puskesmas Muka ditujukan untuk memudahkan petugas mencari dan mengembalikan berkas lebih cepat dari sistem yang sebelumnya diterapkan, meskipun sistem penerapan Nomor File ini masih ditemukan berbagai kendala.

\section{BIBLIOGRAFI}

Anita, B., \& Febriawati, H. (2019). Puskesmas Dan Jaminan Kesehatan Nasional. Deepublish.

Deharja, A. (2021). Buku Ajar Praktik Klinis Rekam Medis (Pengantar Awal Turun 
Lapang). Pelita Medika.

Estera, S. (2018). Implementasi Pelayanan Publik Undang Undang Nomor 25 Tahun 2009 Terhadap Badan Penyelenggara Jaminan Sosial Di Rumah Sakit Umum Daerah Sultan Syarif Mohamad Alkadrie Kota Pontianak. Jurnal Hukum Prodi Ilmu Hukum Fakultas Hukum Untan (Jurnal Mahasiswa S1 Fakultas Hukum) Universitas Tanjungpura, 6(2).

Hidayat, S. (2012). Tinjauan Terhadap Kelengkapan Pengisian Laporan Tindakan Operasi Di Rumah Sakit Pelni Petamburan.

Indonesia, R. (2004). Undang-Undang Nomor 29 Tahun 2004 tentang Praktik Kedokteran. Jakarta: Republik Indonesia.

Maliang, M. I., Imran, A., \& Alim, A. (2019). Sistem Pengelolaan Rekam Medis (Studi Kualitatif Di Puskesmas Tamalate Makassar Tahun 2019). Window of Health: Jurnal Kesehatan, 315-328. https://doi.org/10.33368/woh.v0i0.198

Mandia, S. (2019). Sosialisasi Pelaksanaan Sistem Penyimpanan Berkas Rekam Medis Di Klinik As Salam Kota Padang. LOGISTA-Jurnal Ilmiah Pengabdian Kepada Masyarakat, 3(2), 130-134. https://doi.org/10.25077/logista.3.2.130-134.2019

Permenkes, R. I. (2008). No 269/Menkes/Per/III/2008 tentang Rekam Medis. Jakarta: Menteri Kesehatan Reupublik Indonesia.

Rachma, A. (2018). Sistem Temu Kembali Arsip Rekam Medis Pasien Di Rumah Sakit Hermina Kemayoran. Fakultas Adab \& Humaniora.

Rahayu, N. P., Dahlan, S., \& Soerjowinoto, P. (2016). Penyelenggaraan Rekam Medis Pada Pelayanan Kesehatan Bakti Sosial Oleh Rumah Sakit Umum Daerah Kabupaten Temanggung. SOEPRA, 2(2), 165-174. https://doi.org/10.24167/shk.v2i2.819

RI, D. (2006). Pedoman Penyelenggaraan \& Prosedur Rekam Medis Rumah Sakit di Indonesia Revisi II. REVISI II.

Simanjuntak, E., \& menkes.ris Sirait, L. W. O. (2018). Faktor-faktor penyebab terjadinya missfile di bagian penyimpanan berkas rekam medis rumah sakit mitra medika medan tahun 2017. Jurnal Ilmiah Perekam Dan Informasi Kesehatan Imelda (JIPIKI), 3(1), $370-379$.

Subadi, T. (2006). Metode penelitian kualitatif. Muhammadiyah University Press.

Wahyuni, S. (2021). Sistem Pelaksanaan Penyimpanan Rekam Medis di Kilinik Pratama Bakti Timah Pangkalbalam. Jurnal Health Sains, 2(9), 1255-1262. https://doi.org/10.46799/jhs.v2i9.273

Wiguna, A. S., \& Safitri, D. R. (2019). Tinjauan Sistem Penyimpanan Dokumen Rekam Medis di RSU Sinar Husni Tahun 2019. Jurnal Ilmiah Perekam Dan Informasi Kesehatan Imelda (JIPIKI), 4(2), 648-654.

(C) 2021 by the authors. Submitted for possible open access publication under the 